\title{
The Political and Military Aspects of Accession of Constantine the Great
}

\section{Stanislav Doležal}

(University of South Bohemia in České Budějovice)

\begin{abstract}
The article argues that Constantine the Great, until he was recognized by Galerius, the senior Emperor of the Tetrarchy, was an usurper with no right to the imperial power, nothwithstanding his claim that his father, the Emperor Constantius I, conferred upon him the imperial title before he died. Tetrarchic principles, envisaged by Diocletian, were specifically put in place to supersede and override blood kinship. Constantine's accession to power started as a military coup in which a military unit composed of barbarian soldiers seems to have played an important role.
\end{abstract}

\section{Keywords}

Constantine the Great; Roman emperor; usurpation; tetrarchy 
On 25 July 306 at York, the Roman Emperor Constantius I died peacefully in his bed. On the same day, a new Emperor was made - his eldest son Constantine who had been present at his father's deathbed. What exactly happened on that day? Britain, a remote province (actually several provinces) ${ }^{1}$ on the edge of the Roman Empire, had a tendency to defect from the central government. It produced several usurpers in the past. ${ }^{2}$ Was Constantine one of them? What gave him the right to be an Emperor in the first place? It can be argued that the political system that was still valid in 306, today known as the Tetrarchy, made any such seizure of power illegal. But the question of legitimacy of Constantine's power in 306 is in no way settled. Although the majority of modern scholars today view this act as an usurpation of imperial prerogative ${ }^{3}$ or at least are ready to accept this interpretation, ${ }^{4}$ there are still strong voices claiming that the accession of Constantine was legal. ${ }^{5}$ We will discuss these opinions later, now a detailed analysis of all available evidence is required for a reconstruction of the fateful event.

The chronologically first testimony is an anonymous panegyric of 307. Recapitulating the previous year's events, the speaker turns to Constantine saying that "although your father had left you imperial power, nevertheless you were content with the title of Caesar and preferred to wait for the same man to declare you Augustus who so declared him" (referring to Galerius, the senior Emperor of the Tetrarchy). ${ }^{6}$ The speaker then explains that although Constantine could claim the title of augustus by the right of succession, he preferred to obtain it from Galerius "for his merits" (si id non hereditarium ex successione crevisses, sed virtutibus tuis debitum a summo imperatore meruisses). It is obvious that this passage contains a number of problematic statements and assumptions. The speaker presents to the audience that Constantine was elevated to the imperial rank by his dying father; he implies that Constantine had the choice of either retaining the title of augustus, conferred upon him by Constantius, or accepting the title caesar from Galerius; that Constantine's accession was, if not legal, certainly just and proper; and finally, that Galerius now has no choice but to promote Constantine from caesar to augustus for "his merits". But perhaps the most striking assumption is that the transference of power from father to son constitutes the legality of imperial power (hereditarium imperium ex

1 Barnes (1982: p. 216) lists four provinces for the period after Constantius I reconquered Britain in 296: Prima, Secunda, Maxima Caesariensis, Flavia Caesariensis.

2 Arguably the first usurper on the British Isles was Clodius Albinus (193-197), although he appears to have the same right to rule as did Septimius Severus or Pescennius Niger. It was, however, Severus who succeeded to secure Rome and most of the Empire's territory (for details see Southern 2004: pp. 28-32 and 34-37). In the years 260-274, Britain was ruled in turn by Postumus, Marius, Victorinus and Tetricus - the Emperors of the Gallic Empire. In 296, Constantius I himself removed another usurper, Allectus, who followed Carausius (286-293) as an independent ruler of the Roman Britain.

3 Girardet (2010: p. 27); Humphries (2008: p. 100); Van Dam (2008: p. 36); Lenski (2007: p. 62); Pohlsander (2004: p. 16); Drake (2000: p. 166); Češka (2000: p. 47); Kolb (1997: p. 45; 2001: p. 59); Clauss (1996: p. 21).

4 Potter (2013: p. 112); Drinkwater (2009: p. 185); Southern (2004: p. 170).

5 Barnes (2014: p. 63; 1981: p. 28); Odahl (2013: p. 79); Wienand (2012: p. 120); Stephenson (2010: pp. 116-117); Leadbetter (2009: p. 165).

6 Pan. Lat. VII (6), 5, 3: cum tibi pater imperium reliquisset, Caesaris tamen appellatione contentus exspectare malueris ut idem te qui illum declararet Augustum (Transl. Nixon \& Rodgers 2015: p. 197). 
successione). Such assumption would be certainly correct in previous centuries, but not in the system of Tetrarchy.

The panegyrist of 310 speaks in a similar manner. According to him, Constantius himself, while waging war against the Picts in the north, was presented with a question of whom he would have chosen as his successor - and the Emperor unambiguously named Constantine. ${ }^{7}$ Furthermore, the rhetorician explicitly says that the dying emperor did appoint Constantine as his successor; and finally, he maintained that the accession of Constantine was approved by the whole army (universus exercitus). Allegedly, the soldiers adorned Constantine with purple while he was still weeping for his father - but, as the speaker points out, "it was not right to mourn any longer a ruler who had been consecrated as a god." In order for this farce to be complete, Constantine is said to have tried to escape the enthusiastic soldiers on horseback (diceris etiam, imperator invicte, ardorem illum te deposcentis exercitus fugere conatus equum calcaribus incitasse). ${ }^{8}$

What the panegyrist describes to us here is the so-called rejection of the imperial rank (recusatio imperii), well-known from other cases, although we cannot always verify whether such behaviour on the part of the candidate actually took place; some cases of recusatio imperii are undoubtedly later inventions. For example, on January 17, 379, the Emperor Gratian appointed Theodosius as his co-ruler. None of the standard historical sources mentions any reluctant response of Theodosius to his appointment. ${ }^{9}$ And yet, ten years after this event, Latinius Pacatus Drepanius asserted that Theodosius at first refused the title and had to be persuaded. ${ }^{10}$ In 364, after the death of the Emperor Jovian, the heads of the military and civilian administration elected, after some discussion, a military commander Valentinian as the new Emperor. Our main sources for this event - Ammianus Marcellinus and Zosimus - concur that Valentinian gave no troubles and accepted the promotion. ${ }^{11}$ However, five years after that event, the famous orator Quintus Aurelius Symmachus asserted in his panegyric to Valentinian that "the state is always extremely pleased with the men reluctant to assume the highest power" (nam res publica vehementius delectatur invitis). Valentinian just had to overcome his modesty (verecundia) and show devotion to the state (devotio) by yielding to the will of soldiers. Symmachus concluded: "Sometimes even the bad manners of soldiers are beneficial" (prodest nonnumquam militaris improbitas). ${ }^{12}$ Joachim Szidat considered the problem of recusatio imperii to be something inherent to the panegyrics; after some time, the legitimate emperor wants to make it clear that his reluctance on the day of election distinguishes him from the usurper (who, on the contrary, is always described as a power craving person). ${ }^{13}$

7 Pan. Lat. VI (7), 7, 3: rogatus cui imperium decerneret ... manifeste enim sententia patris electus es, imperator.

8 Pan. Lat. VI (7), 8, 2-4. Transl. Nixon \& Rodgers (2015: p. 230).

9 Oros. Hist. VII, 34, 2; Zos. IV, 24; Epitome 47, 3; Cons. Const. s. a. 379; Socrates HE V, 2; Sozom. HE VII 2 , 1; Theodoret. $H E \mathrm{~V}, 5-6$.

10 Pan. Lat. II (12), 11-12.

11 Amm. Marc. XXVI, 1-2; Zos. III, 36.

12 Symmachus, Laudatio in Valentinianum seniorem Augustum prior 9-10.

13 Szidat (2010: pp. 75-76). 
Now it is time to study other reports, Christian or pagan, which have something to say about the events of July 25, 306. The first is a brief testimony of Lactantius, written in about 315. Lactantius tells how Constantine arrived "at an incredible speed" in Britain where his father was already dying. Constantius "recommended his son to the soldiers and handed him the imperial power." Then he died. ${ }^{14}$ Elsewhere, Lactantius briefly notes that Constantius made his son augustus, not caesar. ${ }^{15}$

The account of Eusebius - a biography of Constantine, written about 33 years after the event - essentially confirms the version of Lactantius. Here, too, Constantine manages to reach his father who is already lying on his deathbed, but Constantius still has enough strength to stand up, embrace his son and say that his only grief - that is, his eldest son's absence - is now gone. Then the Emperor "sent up a prayer of thanks to God (...), gave instructions to his sons and daughters, who gathered round him like a choir, and in the palace itself, on the imperial couch, he handed over his part of the Empire by natural succession to the senior in age among his sons, and expired." 16 There is a slight alteration - Constantius recommends his son not to soldiers, but to family members. Eusebius emphasizes the "natural right" of Constantine to power (which we will discuss later) and his title augustus.

Paulus Orosius, writing around 417, adheres to the belief of hereditary power, too as if there was no political system of Tetrarchy whose part, after all, Constantius was: "Constantius Augustus, the most gentle and mild man, died in Britain and left his son Constantine, born from his concubine Helena, as an Emperor in Gaul." Consequently, Constantine merely "took over the helm of the government from his father" (Constantinus ... gubernacula imperii a Constantio patre suscepit) - again, as if there was no need to fight for it. ${ }^{18}$

Other sources comment on Constantine's accession quite differently. The Origo Constantini imperatoris says that after his victory over the Picts, Constantius died at York, and Constantine became caesar "with the consent of all soldiers." ${ }^{19}$ Aurelius Victor remarked that Constantine wanted to be a ruler from his childhood. When he escaped from the power of Galerius - for he was held in the East as a hostage - he escaped to Britain, where his father was already dying. After his death Constantine seized the power "with

14 Lact. de mort. pers. 24, 8: at ille incredibili celeritate usus pervenit ad patrem iam deficientem, qui ei militibus commendato imperium per manus tradidit.

15 Lact. de mort. pers. 24, 9: Constantinus Augustus; 25, 5: Constantinum vero non imperatorem, sicut erat factus, sed Caesarem.

16 Eusebius, Vita Constantini I, 21. Transl. Cameron \& Hall (1999: p. 78). It is indeed possible that all of his children from his second marriage were present - Flavius Dalmatius, Julius Constantius, Hannibalianus, Constantia, Anastasia and Eutropia. Their ages are not attested but they all were born after the wedding of Constantius with Theodora in 289, so none of them could have been more than sixteen years old in 306. See Barnes (1982: p. 37).

17 Oros. Hist. VII, 25, 16: Constantius vero Augustus summae mansuetudinis et civilitatis in Britannia mortem obiit. Qui Constantinum filium ex concubina Helena creatum imperatorem Galliarum reliquit.

18 Oros. Hist. VII, 26, 1.

19 Origo 2, 4: post victoriam autem Pictorum Constantius pater Eboraci mortuus est et Constantinus omnium militum consensu Caesar creatus. 
the consent of all those who were present." ${ }^{20}$ Eutropius and Jerome simply say that Constantine was "made Emperor in Britain" or that he "seized power" there, but they do not say how it happened. ${ }^{21}$ Nor are of any help two authors of ecclesiastical histories, Socrates Scholasticus and Philostorgius. ${ }^{22}$ The testimony of Zosimus, although hostile to Constantine, is more useful: "It so happened that the emperor Constantius died just then. His praetorian guard, thinking none of his legitimate children worthy of the purple and seeing Constantine in good health, and also excited by hopes of handsome rewards, conferred the rank of Caesar on him."23

Lastly, we possess a brief, but important information left by the anonymous author of the Epitome de Caesaribus. The Epitomator narrates that Constantine "reached his father in Britain; and by chance, in those very days in the same place, ultimate destiny was pressing on his parent, Constantius. With him dead, as all who were present - but especially Crocus, King of the Alamanni, who had accompanied Constantius for the sake of support - were urging him on, he took imperium." ${ }^{24}$ The exact wording is identical to the account of Aurelius Victor, with the remarkable addition of the words sed praecipue Croco, Alamannorum rege, auxilii gratia Constantium comitato. ${ }^{25}$ Only the Epitome tells us this detail and this Crocus is not mentioned by any other sources. Extreme brevity makes the translation of this sentence difficult, but the word auxilii gratia probably means that Crocus commanded an auxiliary unit in the Roman army (auxilium, plural auxilia), which perhaps was composed of the Alamanni. Such troops are indeed attested in the late Roman Empire, albeit in later periods, and not in Britain. ${ }^{26}$ Likewise, the words Constantium comitato, by which the king is characterized, is likely to indicate the king's long presence at the court of Constantius. But what does the term king (rex) actually mean? We know that the Alamanni - by definition a confederation of several tribes living on the

20 Aur. Vict. 40, 2-4: Quod tolerare nequiens Constantinus, cuius iam tum a puero ingens potensque animus ardore imperitandi agitabatur ... in Britanniam pervenit. ... Et forte iisdem diebus ibidem Constantium patrem vel parentem vitae ultima urgebant. Quo mortuo cunctis qui aderant, annitentibus imperium capit. (The words vel parentem, which are difficult to explain, are sometimes omitted from translations, see Bird 1994: p. 179).

21 Eutr. X, 2, 2: verum Constantio mortuo Constantinus ex obscuriore matrimonio eius filius in Britannia creatus est imperator et in locum patris exoptatissimus moderator accessit; Hieronymus, Chronicon s. a. 306: Constantius XVI imperii anno diem obiit in Britannia Eboraci, post quem filius eius Constantinus ex concubina Helena procreatus regnum invadit.

22 Socrates (HE I, 2, 1) simply says that Constantine succeeded his father as the new Emperor; Philostorgius $(H E$ I, 5) narrates that after Constantius died in Britain, Constantine oversaw his funeral and succeeded him as the new ruler.

23 Zos. II, 9, 1. Transl. Ridley (1982: pp. 28-29).

24 Epitome de caesaribus. Transl. Banchich (2018).

25 Epitome 41, 2-3 (Pichlmayr \& Gruendel 1970): ad patrem in Britanniam pervenit; et forte iisdem diebus ibidem Constantium parentem fata ultima perurgebant. Quo mortuo cunctis, qui aderant, annitentibus, sed praecipue Croco, Alamannorum rege, auxilii gratia Constantium comitato imperium capit.

26 See Notitia Dignitatum, Oriens 31 and 32: among other units, dux Thebaidos commanded cohors nona Alamannorum, while dux Phoenices had ala prima Alamannorum and cohors quinta pacta Alamannorum in his small provincial army. It is not surprising that the Notitia knows of no such unit in Britain; the data for this document were probably collected in the end of the 4th century (for the eastern half of the empire) and at the beginning of the 5 th century (for the western half). Moreover, the preserved text has many gaps and whole sections are missing. See Lee (2007: p. 76) and Kelly (2004: p. 40). 
Upper Rhine - had no central government or a single leader at this time. ${ }^{27}$ At most, Crocus could be a leader of one tribe - or perhaps just a part of it - who somehow, at some point, entered the service in the Roman army. That should come as no surprise. We know of many Germanic leaders who had a splendid career in the Empire. A Visigothic petty king Munderic was in 376 subordinated to the higher Visigothic leader Athanaric. Presumably in late 370 s he entered the Roman service, becoming a commander of military units in the Roman province of Arabia (in the territory of present-day Jordan), and perhaps even a governor of this province. ${ }^{28}$

An even better example is the king of the Alamanni Vadomarius, who was captured in 361 by the caesar Julian at the Danubian border, later (between 361-365) becoming the military commander of the province of Phoenice (dux Phoenices), the territory of presentday Lebanon. Still later, in 371, he fought successfully against the Persians in Armenia (being described ex rege Alamannorum - "a former king of the Alamanni"). ${ }^{29}$ It is very clear from our sources that before his service in the Empire, Vadomarius had been only one of many kings of the Alamanni. ${ }^{30}$ But perhaps the most fitting example is the case of certain Fraomarius. In 372, the Emperor Valentinian I "made Fraomarius king of the Bucinobantes, a tribe of the Alamanni dwelling opposite Mainz. And soon afterwards, since a recent invasion had utterly devastated that canton, he transferred him to Britain with the rank of tribune, and gave him command of a troop of the Alamanni which at that time was distinguished for its numbers and its strength." ${ }^{11}$

We do not know how and when Crocus joined the Roman army. He could have been captured with his people somewhere near the Upper Rhine by the Romans or perhaps he volunteered to be hired by the Romans. He had a good opportunity to do so, for example, in the years 287-288, when the Western Emperor Maximian conducted a hard and successful strike against the Alamanni and the Franks. ${ }^{32}$ In 289, a panegyric sums up the achievements of Maximian during this campaign in this way: "So many kings, O Emperor, are your clients, when Gennoboudes recovered his kingdom, thanks to you, indeed received it from you as a gift. For what else did he seek by coming into your presence with all his people other than that he should reign at last with unimpaired authority, now that he had appeased you? He displayed you repeatedly, I hear, to his people, and ordered them to rest their gaze upon you for a long time, and to learn submissiveness, since he himself was subject to you." ${ }^{33}$ Somewhat later, in 291, another panegyric

27 For the political institutions of the Alamanni see Drinkwater (2007: especially pp. 117ff).

28 Amm. Marc. XXXI, 3, 5. Notitia Dignitatum, Oriens 37. It is entirely possible that Munderic's full title was not just dux Arabiae (or dux limitis Arabiae, as reported by Ammianus), but dux et praeses Arabiae. In other words, he may have exercised both civilian and military powers in this province.

29 Amm. Marc. XXI, 3-4; XXVI, 8, 2; XXIX, 1, 2.

30 Although the author of the Epitome de Caesaribus $(42,14)$ described him as „very powerful“ or "the most powerful" among the Alamanni (potentissimum eorum regem Badomarium).

31 Amm. Marc. XXIX, 4, 7. Transl. Rolfe (1939: p. 245). It is noteworthy that Notitia Dignitatum (Oriens 6, 17 and 58) lists a military unit called Bucinobantes which served with the field army of the East. It is possible that some other unit of Bucinobantes served in Britain (see note 26).

32 Kuhoff (2001: pp. 77nn); Southern (2004: p. 142); Potter (2004: p. 283); Williams (2000: pp. 50-51).

33 Pan. Lat. X (2), 10, 3. Transl. Nixon \& Rodgers (2015: p. 68). 
makes the allusion that "the Franks with their king came to beg for peace" (Francos ad petendum pacem cum rege venientes). ${ }^{34}$ This is undoubtedly the same event. We do not know the circumstances, but Gennoboudes was probably defeated in this campaign and forced to ask for peace; the Emperor confirmed him in his territory and power, and the king became, with his Franks, the vassal of the Romans, to his advantage and to the benefit of the Empire. The Franks were definitely crushed several time by Maximian or his generals, but what about the Alamanni?

At the same time, the Alamanni even suffered from the Roman invasions of their territory. A panegyric, written in 297 to commemorate Constantius I and his achievements, speaks of "the capture of the king of a most savage nation while he was in the act of preparing an ambush, and the complete burning and devastation of Alamannia from the Rhine bridge right to the crossing of the Danube at Guntia." ${ }^{55}$ Guntia is today's Günzburg, Bavaria. If a bridge at Mainz is meant here, then the Roman army must have traversed the former agri decumates almost in its entirety - an area which was lost in the 260s and which Maximian now tried to reconquer. This campaign may have taken place in 287 or $288 .{ }^{36}$ Although the speaker proudly claims to have been an eyewitness to these events, he fails to tell us the name of that captured king. However, it is quite possible that it might be our Crocus. But Crocus may have joined the Roman army at any other point, for example after the great victories of Maximian's caesar Constantius I over invading Alamanni at Lingones (Langres, France) and Vindonissa (Windisch, Switzerland), which are difficult to date, but both probably belong to $290 \mathrm{~s}^{37}$

Much later, Gregory of Tours in his chronicle of the Franks mentions the invasion of Gaul by Frankish "dukes" Genobaudes, Marcomer and Sunno, which is said to have taken place in 388. Gregory wrote in the late 6th century but made use of the history of Sulpicius Alexander which was a contemporary source, and which is now regrettably lost. ${ }^{38}$ Elsewhere, Gregory speaks of an Alamannic king named Chrocus, who is said to have devastated Gaul during the reign of Valerianus and Gallienus (253-260), to have been captured at Arles, tortured and executed. ${ }^{39}$ Unless Gregory's narrative is merely a legend, this Chrocus might have been the grandfather of our Crocus, while Genobaudes could have descended from the Frankish king mentioned above. Of course it might be nothing more than a simple reuse of the same name for different leaders,

34 Pan. Lat. XI (3), 5, 4.

35 Pan. Lat. VIII (4), 2, 1 (captus scilicet rex ferocissimae nationis inter ipsas quas moliebatur insidias et a ponte Rheni usque ad Danubii transitum Guntiensem deusta atque exhausta penitus Alamannia). Transl. Nixon \& Rodgers (2015: p. 111). See Drinkwater (2007: p. 181).

36 Year 288: Southern (2004: pp. 142-143); year 287: Potter (2004: p. 283).

37 Sources: Eutr. IX, 23; Pan. Lat. VI (7), 6, 2. For the date, see Nixon \& Rodgers (2015: pp. 225-226, note 25). Cf. Barnes (1982: p. 61) who put these battles to 302 and 303, respectively.

38 Gregory of Tours, Historiarum libri decem II, 9. Frankish chiefs Marcomeres and Sunno are also mentioned by Claudius Claudianus (De consulatu Stilichonis I, 241-243) who says that Marcomer was later (in 390s) captured by Stilicho and exiled to Etruria, while Sunno, vowing to avenge him, was killed by his own men. Claudianus does not know Gennobaudes who was perhaps killed in 388 already. See Drinkwater (2007: p. 318).

39 Gregory of Tours, Historiarum libri decem I, 32 and 34. 
which were unrelated to each other. But Gregory is known to have drawn from good sources in his first two books, and the matching ethnicities are striking: his Genobaudes is a Frank, his Chrocus is an Alamannus. Even if his sources do echo a mere legend, it is a strange coincidence. ${ }^{40}$

Returning to the story of Crocus in the Epitome, his title rex can either mean a former king (like Vadomarius or Fraomarius) or any sort of Alamannic warlord. Either way, his group of warriors did not have to be numerous. Although their exact number and the type of the unit is anybody's guess, ${ }^{41}$ perhaps it contained only some $500-800$ warriors, which is probably the size of new auxiliary units, first introduced by Maximian and mostly composed of the Rhine Germans; Constantine later increased their number and even made them the backbone of his army. ${ }^{42}$ However, John Drinkwater suggested that Crocus commanded a formidable group of 3,000-6,000 men. He preferred to see Crocus essentially as a long-distance war-leader from the region of Upper Rhine who was hired by Constantius. He may be right; but he failed to explain why no source mentions such a large unit. Nor is it quite clear how Constantine disposed of Crocus and his men afterwards. They disappeared without a trace. ${ }^{43}$ It will be safer to assume that they formed a smaller unit well within the structure of the Roman army.

Be it as it may, the number of Crocus' men may not be very important. Being in the right place at the right time seems to have mattered more, especially if there were not many regular Roman units at York on that fateful day (of which we are, alas, not informed). Several hundred elite warriors were probably enough, and their immediate support may have been decisive. And it is clear that Crocus was not afraid to back Constantine's usurpation.

Yes, usurpation - because what happened on 25 July 306 at York was precisely that. Constantine, long determined to become an Emperor, ${ }^{44}$ badly needed any support he could get. Help from a former king of the Alamanni and his barbarian warriors was awkward and certainly nothing to be proud of (which is probably why no other source mentions this detail), but it proved to be sufficient and effective. And although some of our sources quoted above assert that Constantine became the new Emperor with the consent of all those who were present, it is still conceivable that some of the courtiers at York may have wavered between their loyalty to Constantine and to the Tetrarchy, and needed to be persuaded by strong military presence of barbarian warriors to whom personal loyalty to their lord mattered most.

40 However, we should not let our imagination wander, as did Petr Charvát (2010: p. 13) who in all seriousness claimed that the Alamannic king Crocus present in 306 at York was identical to a Crocco (Krok), a strange figure known from Czech myths and legends! See Cosmas Pragensis, Chronica Boemorum I, 3.

41 For example Salway (1993: p. 233): „in command of a cohort of Alamanni“.

42 Lee (2008: p. 214).

43 Drinkwater (2009: pp. 192-193). Drinkwater suggested that Crocus „was probably paid off as soon as possible" and sent back home to Germania.

44 According to Aurelius Victor (40, 2), Constantine's ,proud and capable spirit had been stirred ever since boyhood by the passion to rule" (transl. Bird 1993: p. 46). Cf. note 20. Constantine's ambitions are also emphasized by Eutropius (X, 5) and Zosimus (II, 8, 2-3). 
Although elevated to the imperial power, Constantine was still desperate for legitimacy. It is questionable whether Constantius handed his son his imperial power at all and even if he did, he must have been fully aware that he had no right, or at least no exclusive right, to name his successor. The remaining three Emperors also had that honour. The best Constantius could do was to recommend his son to his colleagues for their consideration. But, given the hostility of Galerius towards Constantine, it would probably have been a futile gesture and it is not surprising that no source indicates such course of action of the dying Emperor. That was the beauty of the tetrarchic system: should any of the senior Emperors unexpectedly die, his caesar was prepared to take his place. It is true that in such case, as in the case of a sudden death of a caesar, there still had to be a discussion in the imperial college regarding the selection of a new caesar. But the death of an augustus automatically meant the promotion of his caesar to the rank of augustus. This was the essence of the Tetrarchy, this was how Diocletian wanted the system to work. Therefore, Flavius Valerius Severus was to become - and duly became the new augustus in the West. ${ }^{45}$

Constantine was doubtless aware of the problem of legitimacy, as his feigned recusatio imperii indicates. ${ }^{46}$ It is also noteworthy that only Eusebius, Lactantius, Orosius and the two panegyrics claim that Constantine was made Emperor by the will of his father. Four other sources (Eutropius, Jerome, Philostorgius and Socrates Scholasticus) refrain from making such a statement, and the four remaining sources imply a decisive role of either courtiers (Aurelius Victor, Epitome) or the troops on the spot (Origo, Zosimus). Constantine, obviously, informed Galerius that it was the will of his father what made him accept the promotion. ${ }^{47}$ He may have lied, but it hardly mattered - such assertion was grave enough by itself, regardless of the truth. Here we should insert an interesting sidenote: what title was conferred by soldiers and courtiers upon Constantine on 25 July 306 ? Constantine would have acted very sensibly if he contented himself with the title caesar from the start. To preserve the Tetrarchy, this title had to be bestowed on someone anyway, since Severus now became the new Western augustus and thus a vacancy was created. Although it could be expected that Galerius would be offended when presented with this fait accompli, the lower title meant a better chance to be recognized. Indeed, some of our sources speak unambiguously about the rank of caesar: the panegyrics, the Origo and Zosimus. ${ }^{48}$ On the other hand, only Eusebius and Lactantius maintain that Constantine was made augustus, no less. The rest of our sources - Eutropius, Socrates Scholasticus, Aurelius Victor, Epitome, Philostorgius, Orosius and Jerome - indicate or imply the title augustus. If Constantine reached for the title augustus, he expressed both his lack of patience and his determination to unleash civil war, if necessary.

45 Barnes (2014: p. 68) rightly remarked that Severus „automatically advanced in rank from Caesar to Augustus when Constantius died“.

46 That is, if it ever happened - as discussed previously, it may be a later invention.

47 Lact. de mort. pers. 25, 1-3. Constantine also sent Galerius his laurelled portrait.

48 Pan. Lat. VI (7), 8, 2: O fortunata et nunc omnibus beatior terris Britannia, quae Constantinum Caesarem prima vidisti!, cf. Pan. Lat. VII (6), 5, 3. 
Nevertheless, both Constantine and Galerius intended to avoid a war - although the latter is said to be furious when he learned of Constantine's usurpation; that is understandable as both the tetrarchic principles and Galerius' own authority were flouted by that act. Simply by the death of Constantius, Galerius suddenly became the first in the imperial college, Severus - the new augustus of the West - being the second and Maximinus Daia, the Eastern caesar, the third. Constantine was to receive the fourth place in the tetrarchic hierarchy - if any at all. Galerius was now presented with three options: to try to displace Constantine by force, to ignore him, or to recognize him as the new caesar in the West. Constantine's claim - whether true or not - that his power stemmed from the superior authority (the will of his father) made any military action precarious. Not only would his removal have been risky, but how could it be justified? It cannot be denied that blood kinship still had some weight in the tetrarchic system. Galerius himself nominated his relative Maximinus Daia as the Eastern caesar in 305, and Diocletian approved of his choice. ${ }^{49}$ Moreover, the stance of the new Western augustus Severus is unknown to us perhaps he was reluctant to take any action against Constantine. Ignoring Constantine would not have helped Galerius either. Someone else would have had to be named as the new Western caesar and civil war would thus only have been postponed, not avoided. It was perhaps also important that Galerius knew Constantine personally - with an unknown entity he would have been in an even more difficult situation. With a bit of luck, recognizing Constantine as caesar could have removed the danger of civil war for good.

Regardless whether Constantine considered himself a caesar or an augustus and in spite of mutual hostility, Galerius acted reasonably. He decided that Constantine would be the Western caesar, and Constantine accepted the offer. Thus, still in 306, Constantine became the new member of the imperial college with the rank of caesar and his usurpation was effectively legitimized. Lactantius asserted that Galerius sent Constantine a purple robe on his own initiative, pretending that his promotion was premeditated and that he had planned to invest him from the beginning. ${ }^{50}$ And to add insult to injury, he denied his father Constantius divine honours. ${ }^{51}$ However, by accepting a subordinate role in the "third Tetrarchy" Constantine at last obtained legitimacy. ${ }^{52}$

As we have seen, some scholars claim that Constantine was not an usurper. Timothy Barnes asserted that Constantine was "long groomed for the throne" ${ }^{153}$ and that he was "an heir presumptive to the imperial purple" ${ }^{54}$ Barnes closely follows Lactantius who

49 Lact. de mort. pers. 18, 13-14.

50 Lact. de mort. pers. 25, 3: ipsi purpuram misit, ut ultro ascivisse illum in societatem videretur.

51 Leadbetter (2009: p. 166).

52 While the first Tetrarchy ended on 1 May 305 and the second Tetrarchy lasted until the death of Constantius, the third Tetrarchy lasted for a short period from the moment when Galerius recognized Constantine as caesar (presumably in August or September 306) until Severus was forced to abdicate in spring 307 (Barnes 1982: pp. 4-6, 28-29). The imperial college, such as it was, comprised (in order of precedence) Galerius, Severus, Maximinus Daia and Constantine (obviously not including the usurpers Maximian and Maxentius).

53 Barnes (1981: p. 28).

54 Barnes (2014: p. 47). 
tells us an astonishing story about the position of Constantine at the court of Diocletian: the elderly Emperor is said to have planned in 305 the elevation of young Constantine to the rank of caesar, although he was then a mere tribune. Lactantius even asserts that everyone was surprised when Constantine was not promoted to that rank on 1 May $305 .{ }^{55}$ To quote but two other scholars, this story of Lactantius "is fraught with inconsistencies and illogicalities and is difficult to take seriously," ${ }^{56}$ as it is "clearly fictional and marked by Lactantius's prejudice." ${ }^{57}$ More to the point, other sources tell us that Constantine was a mere hostage at the court of Diocletian. ${ }^{58}$ In another attempt to demonstrate the legality of Constantine's accession to power, Barnes asserted that Constantius, before he died, "exercised his right as the senior of the two Augusti to appoint a new emperor to the imperial college." ${ }^{59}$ Leadbetter concurs: "Constantine did not usurp power, but received it in the same way as his colleagues and predecessors had: at the hands, and by the patronage, of a superior." 60 Actually, he did not. Constantine "clearly accepted his promotion as emperor by the troops at York in 306 and only later sought to have his legitimacy sanctioned by Galerius." ${ }^{61}$ In other words, he was a typical military usurper. ${ }^{62}$ At the time of Constantine's accession to power, Britain was notable for usurpations and Constantine simply became a part of that tradition. ${ }^{63}$

However, in the system of Tetrarchy, still valid in 306, there was no room for such behaviour, as the case of Maximian's son Maxentius clearly shows. Maxentius, possibly encouraged by Constantine's successful acclamation, had himself proclaimed Emperor by praetorians in Rome on 28 October 306 and quickly gained control of central and southern Italy, Sicily, Sardinia, Corsica and Africa. Notwithstanding that at first he avoided the title augustus and contented himself with the title princeps, ${ }^{64}$ it was clearly an usurpation and Severus, acting now as the new Western augustus, was duly ordered by Galerius to put down this revolt. In what respect were cases of Constantine and Maxentius different? Our sources describe the elevation of Maxentius as a military coup d'état, despite the fact

55 Lact. de mort. pers. 18-19.

56 Leadbetter (2009: p. 137).

57 Corcoran (2012: p. 6).

58 Origo 2, 2: obses apud Diocletianum et Galerium; Aur. Vict. 40, 2: nam is a Galerio religionis specie ad vicem obsidis tenebatur; Epitome 41, 2: hic dum iuvenculus a Galerio in urbe Roma religionis specie obses teneretur.

59 Barnes (2014: p. 63)

60 Leadbetter (2009: p. 165). Stephenson (2010: p. 116) presents yet another view. He claims that Constantine had an agreement with Galerius that if his father dies, he would become the Western caesar. That his soldiers were overzealous and proclaimed him augustus was not, of course, Constantine's fault. Constantine immediately explained the matter to Galerius who without fuss or delay confirmed his promotion to the rank of caesar. This explanation deprives Constantine of the initiative which Stephenson has to attribute to the army; in addition, the hostile relationship of Galerius to Constantine, attested by Lactantius, is ignored. And as mentioned above, our sources are divided on the question what title Constantine gained on 25 July 306.

61 Humphries (2008: p. 87).

62 Kolb (2001: p. 59) even speaks of „eine klassische Usurpation im Stil der Soldatenkaiserzeit des 3. Jhs.“

63 For the tradition of military usurpers in Britain, see note 2.

64 Barnes (1982: p. 13). 
that just like Constantine, Maxentius was a son of an Emperor. ${ }^{65}$ If Constantine claimed that he was made Emperor by the will of his father, Maxentius felt like using his father to solidify his position, too. He sent the imperial purple to Maximian who was living in retirement which had been forced upon him by Diocletian a mere year ago. Maximian thus in late 306 became an Emperor again, although even the title he obtained from Maxentius showed that he was something of a resurrected Emperor - "an augustus for the second time" (bis augustus). ${ }^{6}$ The natural death of Constantius and the political death of Maximian were thus utilized to full extent by their sons.

As has already been pointed out, the transference of power from father to son (or, in the case of Maximian, from a son to his father) had no place in the system of Tetrarchy. It may have constituted the legality of imperial power during the Principate, but by 293 the dynastic principle was clearly superseded by the system of Tetrarchy. The tetrarchic principles, supported by marriages and adoptions, were meant to override blood kinship. The claim of legality of Constantine's power in 306, upheld by some scholars, is based on two considerations: first, that Constantine was the son of a ruling Emperor, and second, that Constantine accepted the imperial power from a superior authority. But the dynastic principle was deliberately suppressed by Diocletian in favor of the meritocracy; and the power of the Western augustus, impressive though it was, did not include the right to elevate anyone to the imperial rank. Besides, Constantine's claim that he received the imperial power from his father must be doubted. ${ }^{67}$ However, his claim was politically strong enough to complicate things for Galerius who hesitated to label Constantine as an usurper.

The system of Tetrarchy was a revolutionary one. Diocletian succeeded in his selection of the most responsible and capable rulers and had the necessary authority to enforce this unusual system of continuity of imperial power. However, the system introduced by him only worked as long as Diocletian himself was in power. It can be argued that after his abdication, the collapse of the system was inevitable. ${ }^{68}$ But the Tetrarchy was still salvageable in late 306 when a gang of two usurpers was formed in the West and the third one, Constantine, barely gained the recognition. In all other aspects was Constantine's case no different from revolts of Maxentius or Carausius who rebelled against the established system and failed. Constantine's desperate efforts in 306 and the following years to solidify his position by various means were ultimately successful and resulted in a number of embellishments of his story. The most prominent of them, Life of Constantine by Eusebius, asserted that everyone present at York on 25 July 306 "with unanimous

65 The military aspects are especially highlighted by Zosimus (II, 9) and Lactantius, De morte pers. 26, 1-2; see also Oros. Hist. VII, 28, 5; Eutr. X, 2; Origo 3, 5; Aur. Vict. 40, 5; and Epitome 40, 2.

66 Lact. de mort. pers. $26,7$.

67 Kolb (2001: p. 59): „es gibt kein zuverlässiges Indiz dafür, dass sein Vater Constantius ihn ... zu seinem Nachfolger ernannt hätte“.

68 Kolb (1997: p. 45): „Die Tetrarchie als Regierungssystem war folglich ein kurzfristiges Experiment auf hohem organisatorischen und ideologischen Niveau, aber insbesondere von ihren moralischen Voraussetzungen her, welche auf der völligen Loyalität und Disziplin des Herrscherkollegiums beruhten, zu anspruchsvoll. Daher musste sie scheitern.“ 
consent praised the accession of the son as a new life for the dead." 69 But the conspicuous presence of Crocus and his men suggests otherwise.

\section{Bibliography}

Banchich, T. M. (Transl.). (2018). Epitome De Caesaribus (Canisius College Translated Texts, 1). Buffalo: Canisius College.

Barnes, T. D. (1981). Constantine and Eusebius. Cambridge, Mass. - London: Harvard University Press.

Barnes, T. D. (1982). The New Empire of Diocletian and Constantine. Cambridge, Mass. - London: Harvard University Press.

Barnes, T. D. (2014). Constantine. Dynasty, Religion and Power in the Later Roman Empire. Chichester: Wiley Blackwell.

Bird, H. W. (Transl.). (1993). Eutropius: Breviarium. Liverpool: Liverpool University Press.

Bird, H. W. (Transl.). (1994). Aurelius Victor: De Caesaribus. Liverpool: Liverpool University Press.

Cameron, A., \& Hall, S. G. (Transl.). (1999). Eusebius: Life of Constantine. Oxford: Clarendon Press.

Charvát, P. (2010). The Emergence of the Bohemian State. Leiden - Boston: Brill.

Clauss, M. (1996). Konstantin der Große und seine Zeit. München: C. H. Beck.

Corcoran, S. (2012). Grappling with the Hydra: Co-ordination and Conflict in the Management of Tetrarchic Succession. In G. Bonamente, N. Lenski, \& R. Lizzi Testa (Eds.), Costantino prima e dopo Costantino: Constantine before and after Constantine (pp. 3-15). Bari: Edipuglia.

Češka, J. (2000). Zánik antického světa. Praha: Vyšehrad.

Drake, H. A. (2000). Constantine and the Bishops. The Politics of Intolerance. Baltimore - London: The John Hopkins University Press.

Drinkwater, J. F. (2007). The Alamanni and Rome 213-496 (Caracalla to Clovis). Oxford: Oxford University Press.

Drinkwater, J. F. (2009). Crocus, “King of the Alamanni”. Britannia, 40, 185-196.

Girardet, K. M. (2010). Der Kaiser und sein Gott. Das Christentum im Denken und in der Religionspolitik Konstantins des Großen. Berlin - New York: De Gruyter.

Humphries, M. (2008). From Usurper to Emperor: The Politics of Legitimation in the Age of Constantine. Journal of Late Antiquity, 1, 82-100.

Kelly, Ch. (2004). Ruling the Later Roman Empire. Cambridge, Mass. - London: Belknap Press of Harvard University Press.

Kolb, F. (1997). Die Gestalt des spätantiken Kaisertums unter besonderer Berücksichtigung der Tetrarchie. In F. Paschoud, \& J. Szidat (Eds.), Usurpationen in der Spätantike (pp. 35-46). Stuttgart: Franz Steiner Verlag.

Kolb, F. (2001). Herrscherideologie in der Spätantike. Berlin: Akademie-Verlag.

Kuhoff, W. (2001). Diokletian und die Epoche der Tetrarchie. Frankfurt am Main: Lang.

Leadbetter, B. (2009). Galerius and the Will of Diocletian. London - New York: Routledge.

Lee, A. D. (2007). War in Late Antiquity. A Social History. Malden: Blackwell.

69 Eusebius, Vita Constantini I, 22, 1. Transl. Cameron \& Hall (1999: p. 78). 
Lee, A. D. (2008). The Army. In A. Cameron, \& P. Garnsey (Eds.), The Cambridge Ancient History, Volume XIII, The Late Empire, A.D. 337-425 (pp. 211-237). Cambridge: Cambridge University Press.

Lenski, N. (2007). The Reign of Constantine. In N. Lenski (Ed.), The Cambridge Companion to the Age of Constantine (pp. 59-90). Cambridge: Cambridge University Press.

Nixon, C. E. V., \& Rodgers, B. S. (2015). In Praise of Later Roman Emperors: The Panegyrici Latini. Berkeley - Los Angeles - Oxford: University of California Press.

Odahl, Ch. M. (2013). Constantine and the Christian Empire. London - New York: Routledge.

Pichlmayr, F., \& Gruendel, R. (Eds.). (1970). Sexti Aurelii Victoris Liber de caesaribus. Leipzig: Teubner.

Pohlsander, H. A. (2004). The Emperor Constantine. New York: Taylor and Francis e-Library. Potter, D. S. (2004). The Roman Empire at Bay AD 180-395. London - New York: Routledge.

Potter, D. S. (2013). Constantine the Emperor. Oxford: Oxford University Press.

Ridley, R. T. (Transl.). (1982). Zosimus: New History. Canberra: Central Printing.

Rolfe, J. C. (Transl.). (1939). Ammianus Marcellinus: History, Volume III: Books 27-31 (Loeb Classical Library, 331). Cambridge, Mass.: Harvard University Press.

Salway, P. (1993). A History of Roman Britain. Oxford: Oxford University Press.

Southern, P. (2004). The Roman Empire from Severus to Constantine. New York: Taylor and Francis e-Library.

Stephenson, P. (2010). Constantine: Roman Emperor, Christian Victor. New York: The Overlook Press.

Szidat, J. (2010). Usurpator tanti nominis. Kaiser und Usurpator in der Spätantike (337-476 n. Chr.). Stuttgart: Franz Steiner Verlag.

Van Dam, R. (2008). The Roman Revolution of Constantine. Cambridge: Cambridge University Press. Wienand, J. (2012). Der Kaiser als Sieger. Metamorphosen triumphaler Herrschaft unter Constantin I.

Berlin: Akademie-Verlag.

Williams, S. (2000). Diocletian and the Roman Recovery. New York - London: Routledge.

PhDr. Stanislav Doležal, Ph.D. / dolezal@ff.jcu.cz

Institute of History

University of South Bohemia in České Budějovice, Faculty of Philosophy

Branišovská 31a, 37005 České Budějovice, Czech Republic 